\section{Response to: 'Role of interaction between B cells and epithelial cells in pSS' by Pringle et al}

We thank Pringle et al for their interest and their comments ${ }^{1}$ concerning our recent article demonstrating how salivary gland epithelial cells (SGECs) from patients with primary Sjögren's syndrome (pSS) can induce survival and activation of B cells. ${ }^{2}$ They are rising six very interesting questions:

(1) F Kroese's group has extensively studied B cells expressing FcRL4 in pSS. ${ }^{3}$ They have shown that this $\mathrm{B}$ cell subset is highly proliferating, express activation markers and participates to the formation of lymphoepithelial lesions. Interestingly, they have shown that FcRL4 mRNA was increased in parotid from patients with pSS with mucosa-associaed lymphoid tissue (MALT) lymphoma. FcRL4 could promote innate signalling in response to chronic antigenic stimulation. For all these reasons, it is tempting to speculate that FcRL4+ B cells could be involved in the crosstalk with SGECs. ${ }^{5}$ We looked at FcRL4 expression in our RNA-seq data set (figure 1A). We did not detect FcRL4 mRNA in blood, nor in salivary gland biopsy. This could be explained by the fact that FcRL4 is likely to be more expressed within parotid ${ }^{3}$ and our study exclusively involved minor salivary gland biopsies.

(2) Pringle et al wonders about the choice of total circulating B cells in the co-culture. We totally agree that co-culture with specific B cells subsets mainly present within the glands such as FcRL4+ B cells or CD27+ and CD27- B cells would be of interest. But sorting sufficient number of B cells from minor salivary gland that measures around $2-3 \mathrm{~mm}$ is, at this time, technically impossible. Plasma cells are another B cell subset infiltrating salivary glands in pSS. ${ }^{6}$ We tried to differentiate blood B cells into plasmablasts and then performed co-culture with SGECs, but the viability was too low to allow fine assessment of the crosstalk.

(3) Pringle et al wondered why we did not used specific B cells stimulation in our co-culture. However, we made the hypothesis that SGECs could stimulate B cells by themselves without any stimulation, and thus we did not want to artificially stimulate them with the adjunction of cytokines or anti- $\mu$. We used TLR3 stimulation in our co-culture models for mimicking a viral trigger, which could reinforce the ability of SGECs from patients with pSS to increase B-lymphocytes survival.

(4) Pringle et al have carefully analysed the profile of gene expression in SGECs provided in our study. We purified CD326+ SGECs, B lymphocytes, CD4 and CD8 T cells from salivary glands. In spite of this sorting, we found in some SGECs samples, some immunoglobulin genes due to a minor contamination by $\mathrm{B}$ cells expressing a high level of immunoglobulins genes. We excluded these samples from the analysis. The level of expression of some immune genes (BTK, CD8a and IGHG1) in SGECs, noticed by Pringle et al, was very low as shown in the figure 1B-D.

(5) Regarding CD326 + epithelial cells, we do agree that they can be either acinar or ductal. Based on the previous work by others on this type of culture, ${ }^{7}$ we presume that they are rather ductal cells. However, it would be even more interesting if acinar cells that are the effective cells secreting saliva could also activate B cells.

(6) Finally, Pringle et al suggest that the two-dimensional co-culture might be too simplistic. We completely agree. This simple model just allows demonstrating the proof of concept that SGECs are able to activate B cells and that this phenomenon is increased with SGECs from patients with pSS. Development of threedimensional approaches with organoids is promising. Of note, our group is currently working on a simpler model, which is the culture of a whole minor salivary gland that will also help to unravel from the inside lymphocyte infiltration within salivary glands. ${ }^{8}$
A
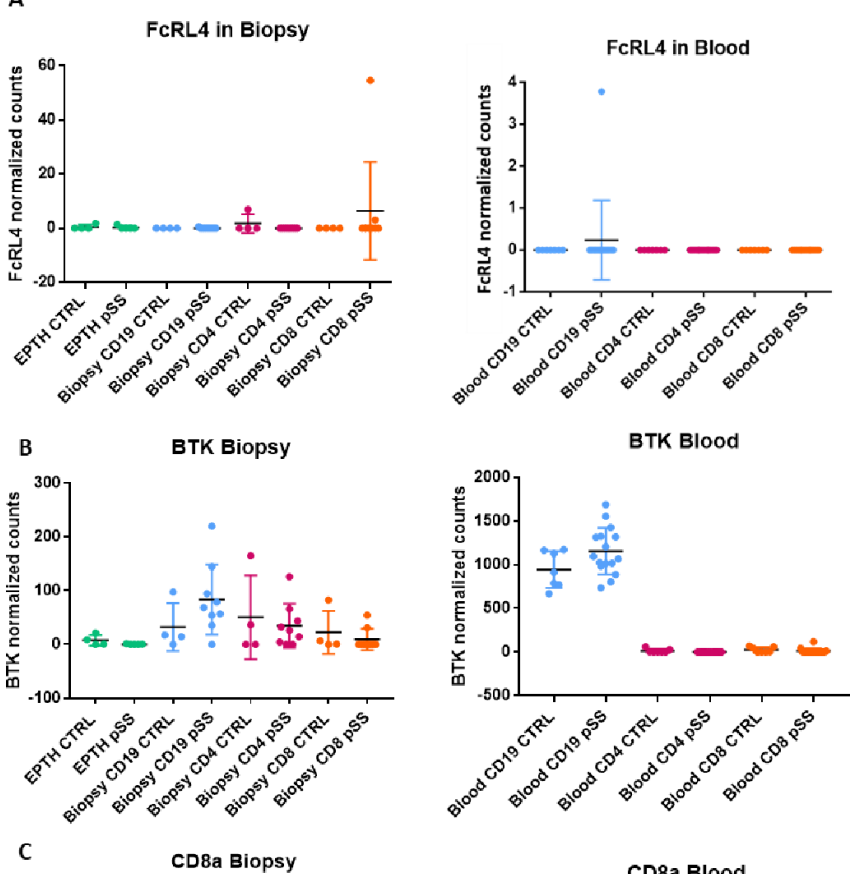

CD8a Blood
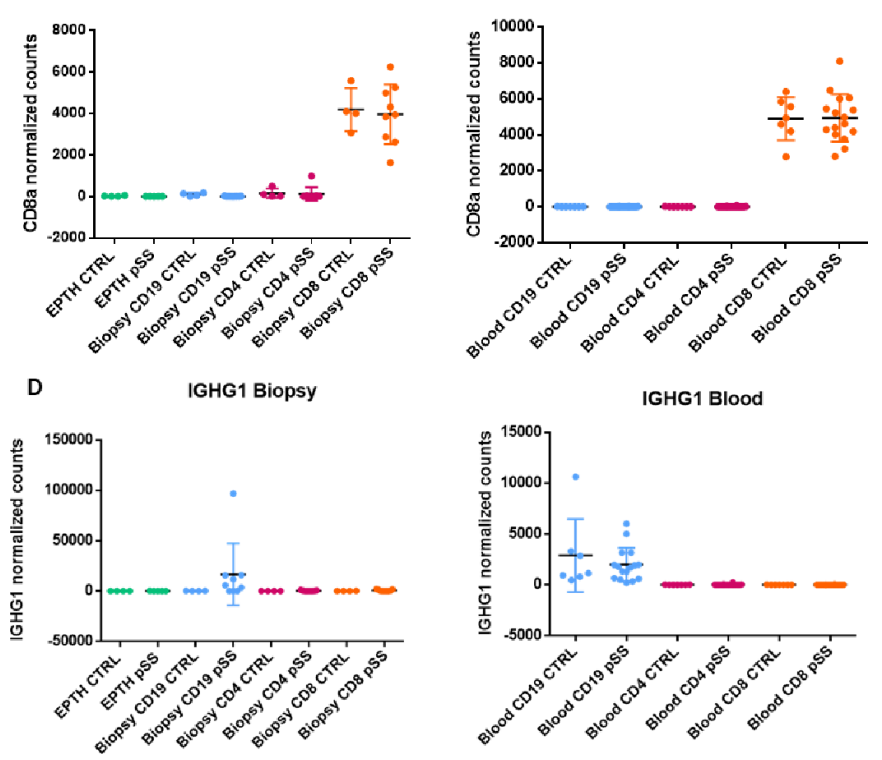

Figure 1 Representation of the normalised counts of FCRL4 (A), BTK (B), CD8a (C) and IGHG1 (D) in salivary gland epithelial cells, CD19+ $B, C D 4+$ and CD8+ T lymphocytes sorted from biopsies (left panel) and CD19+ B, CD4+ T and CD8+ T lymphocytes sorted from blood (right panel), in controls and in primary Sjögren's syndrome (pSS).

Elodie Rivière $\odot,^{1,2}$ Xavier Mariette, ${ }^{1,2}$ Gaetane Nocturne $\circledast^{1,2}$

${ }^{1}$ Immunology of Viral Infections and Autoimmune Diseases, IDMIT, CEA, Université Paris-Sud, INSERM U1184, Le Kremlin-Bicêtre, Île-de-France, France

${ }^{2}$ Rheumatology, APHP, Université Paris-Sud, Le Kremlin-Bicêtre, Île-de-France, France

Correspondence to Dr Gaetane Nocturne; gaetane.nocturne@aphp.fr

Handling editor Josef S Smolen

Contributors ER participated in designing the research studies, conducting experiments, acquiring data, analysing data and writing the manuscript.XM and GN participated in designing the research studies, conducting experiments, analysing data and writing the manuscript

Funding This study was funded by Labex in Research on Medication and Therapeutic Innovation (Grant number: ANR10); Fondation pour la Recherche Médicale (DEQ20150934719); Biogen to Université Paris-Sud (UPSud/SAIC N 
97731); Arthritis R\&D (CIFRE 2016/1406); Innovative Medicines Initiative 2 Joint Undertaking (NECESSITY grant agreement number 806975).

Competing interests None declared.

Patient and public involvement Patients and/or the public were not involved in the design, or conduct, or reporting, or dissemination plans of this research.

Patient consent for publication Not required.

Ethics approval This study received approval from the local ethics committee, and informed consent was obtained from all participants.

Provenance and peer review Commissioned; internally peer reviewed.

(C) Author(s) (or their employer(s)) 2020. No commercial re-use. See rights and permissions. Published by BMJ.

\section{A) Check for updates}

To cite Rivière E, Mariette X, Nocturne G. Ann Rheum Dis Epub ahead of print: [please include Day Month Year]. doi:10.1136/annrheumdis-2020-219096

Received 26 September 2020

Revised 30 September 2020

Accepted 30 September 2020

\section{S Linked}

http://dx.doi.org/10.1136/annrheumdis-2020-219079

Ann Rheum Dis 2020;0:1-2. doi:10.1136/annrheumdis-2020-219096

\section{ORCID iDs}

Elodie Rivière http://orcid.org/0000-0003-1010-3081

Gaetane Nocturne http://orcid.org/0000-0001-6809-0733

\section{REFERENCES}

1 Pringle $\mathrm{S}$, Verstappen $\mathrm{G}$, Bootsma $\mathrm{H}$, et al. Role of interaction between $\mathrm{B}$ cells and epithelial cells in pSS. Ann Rheum Dis 2020:doi: 10.1136/annrheumdis-2020-219079.

2 Rivière E, Pascaud J, Tchitchek N, et al. Salivary gland epithelial cells from patients with Sjögren's syndrome induce B-lymphocyte survival and activation. Ann Rheum Dis 2020:10.1136/annrheumdis-2019-216588.

3 Haacke EA, Bootsma H, Spijkervet FKL, et al. FcRL4+ B-cells in salivary glands of primary Sjögren's syndrome patients. J Autoimmun 2017;81:90-8.

4 Verstappen GM, Ice JA, Bootsma H, et al. Gene expression profiling of epitheliumassociated FCRL4 $4^{+}$B cells in primary Sjögren's syndrome reveals a pathogenic signature. J Autoimmun 2020;109:102439.

5 Sohn HW, Krueger PD, Davis RS, et al. FcRL4 acts as an adaptive to innate molecular switch dampening BCR signaling and enhancing TLR signaling. Blood 2011:118:6332-41

6 Mingueneau M, Boudaoud S, Haskett S, et al. Cytometry by time-of-flight immunophenotyping identifies a blood Sjögren's signature correlating with disease activity and glandular inflammation. J Allergy Clin Immunol 2016;137:1809-21. e12.

7 Dimitriou ID, Kapsogeorgou EK, Abu-Helu RF, et al. Establishment of a convenient system for the long-term culture and study of non-neoplastic human salivary gland epithelial cells. Eur J Oral Sci 2002;110:21-30.

8 Nocturne G, Pascaud J, Rivière E. Primary Sjogren's Syndrome (pSS) IL7 Promotes the Crosstalk Between T Lymphocytes and Salivary Gland Epithelial Cells and Participates to IFN Signature. ACR Meet. Abstr. Available: https://acrabstracts.org/abstract/inprimary-sjogrens-syndrome-pss-il7-promotes-the-crosstalk-between-t-lymphocytesand-salivary-gland-epithelial-cells-and-participates-to-ifn-signature 